\title{
A non-haemagglutinating form of Clostridium difficile toxin $\mathrm{A}$
}

\author{
S. KAMIYA and S. P. BORRIELLO*
}

Microbial Pathogenicity Research Group, MRC Clinical Research Centre, Watford Road, Harrow, Middlesex HA1 3 UJ

\begin{abstract}
Summary. Analysis of crude culture filtrate of Clostridium difficile by Mono Q-anion exchange fast protein liquid chromatography (FPLC) demonstrated that toxin A had distinct peaks of activity for cytotoxicity and haemagglutination, as also did highly purified toxin A obtained by thyroglobulin affinity chromatography (TG) followed by two sequential anion-exchange chromatographic steps with Q-Sepharose FF and Mono Q. From TG unbound fractions a highly cytotoxic but weakly haemagglutinating variant (toxin $A^{\prime}$ ) of toxin A was obtained by Q-Sepharose FF and Mono Q chromatography. Analysis of toxins A and $A^{\prime}$ from cultures of $C$. difficile in a chemically defined medium, and of toxin A dialysed against brain heart infusion broth, indicated that $\mathrm{A}^{\prime}$ was not merely toxin $\mathrm{A}$ coupled to a component of the growth medium. Polyacrylamide gel electrophoresis under non-denaturing conditions showed that toxins $A$ and $A^{\prime}$ had the same $\mathbf{M}_{r}$. Immunoblotting with mouse monospecific $A$ antitoxin showed that five bands larger than the major $240-\mathrm{Kda}$ band were more strongly developed in toxin $\mathrm{A}$ than in $\mathrm{A}^{\prime}$ in denaturing but non-reducing conditions, and in reducing conditions eight bands (38-175 Kda) were seen in toxin A but not $A^{\prime}$. Immunoblotting with a monoclonal antibody (PCG-4) showed that, in both reducing and non-reducing conditions, two bands of 160 and $155 \mathrm{Kda}$ were more prominent in toxins $\mathrm{A}$ and $\mathrm{A}^{\prime}$ respectively, and four bands $(195,180,175$ and $125 \mathrm{Kda})$ were detected only in toxin $A^{\prime}$.
\end{abstract}

\section{Introduction}

Clostridium difficile, the causative agent of pseudomembranous colitis (PMC) and many cases of antibiotic-associated diarrhoea, ${ }^{1-4}$ produces at least two toxins, designated A (enterotoxin) and B (cytotoxin). Toxin A probably causes most of the symptoms associated with PMC because (a) only toxin A induces extensive tissue damage and fluid response in experimental animals, ${ }^{5-7}$ and (b) the severity of the symptoms in antibiotic-associated ileo-caecitis in hamsters is more closely related to the in-vivo production of toxin A than of toxin B. ${ }^{8}$ However, toxins A and B act synergically., 7,9

Toxin A binds to brush border membranes of hamsters; it also haemagglutinates rabbit erythrocytes at $4^{\circ} \mathrm{C}$ but not at $37^{\circ} \mathrm{C} .{ }^{10}$ The binding of toxin $A$ to bovine thyroglobulin showed a similar dependence on temperature. ${ }^{10}$ The binding site was identified as a glycoprotein containing the non-reducing terminal sequence Gal $\alpha 1-3 \mathrm{Gal} \beta 1-4 \mathrm{GlcNAc}$, but other Gal $\beta 1$ 4GlcNAc-containing glycoproteins are thought to be the gastrointestinal mucus receptors for toxin A. ${ }^{11}$ The temperature-dependent binding of toxin $A$ to bovine thyroglobulin has recently been used to purify

Received 3 April 1991 ; accepted 7 May 1991.

*Correspondence should be sent to Dr S. P. Borriello. toxin $\mathrm{A},{ }^{12}$ though small amounts of toxin $\mathrm{B}$ and other proteins are present in the thermal eluent at $37^{\circ} \mathrm{C} .{ }^{13}$ A modified method of purification consists of two sequential anion-exchange chromatographic steps following thyroglobulin affinity chromatography. ${ }^{14}$

Toxin A agglutinates rabbit erythrocytes; toxin B does not do so, ${ }^{10,13}$ although some authors disagree. ${ }^{15}$ In the present study, the relationship between cytotoxicity and the haemagglutinating activity of toxin A, and evidence for a non-haemagglutinating form of the toxin were examined.

\section{Materials and methods}

\section{Bacterial strain and culture filtrate}

C. difficile strain VPI 10463 (originally obtained from Dr T.D. Wilkins, Virginia Polytechnic Institute and State University, Blacksburg, VA, USA) was kindly provided by $\mathrm{Dr}$ M. Giuliano (Laboratorio di Bacteriologia e Micologia Medica, Instituto Superiore di Sanita, Rome, Italy). Its growth in dialysis tubing and the preparation of culture filtrate were as described previously. ${ }^{13}$ After anaerobic incubation $\left(18 \mathrm{~h}, 37^{\circ} \mathrm{C}\right)$ in $10 \mathrm{ml}$ of Brain Heart Infusion Broth (BHI; Oxoid) containing yeast extract (Beta Lab, Surrey) $0.5 \% \mathrm{w} / \mathrm{v}$, L-cysteine- $\mathrm{HCl}$ (BDH Chemicals) $0.05 \%$ and sodium 
formaldehyde sulphoxylate $0.03 \%$, the culture was centrifuged at $3670 \mathrm{~g}$ and $4^{\circ} \mathrm{C}$ and the pelleted bacterial cells were resuspended in $10 \mathrm{ml}$ of phosphate-buffered

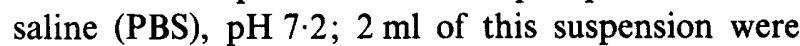
inoculated into dialysis tubing containing $c .100 \mathrm{ml}$ of PBS which had been equilibrated overnight against BHI. After anaerobic incubation for 5 days at $37^{\circ} \mathrm{C}$, the contents of the dialysis tubing were centrifuged at $3670 \mathrm{~g}$ and $4^{\circ} \mathrm{C}$ for $20 \mathrm{~min}$; the culture supernate was retained and filtered $(0.45 \mu \mathrm{m})$.

\section{Bovine thyroglobulin affinity chromatography}

The method was based on that of Krivan and Wilkins ${ }^{12}$ as described previously. ${ }^{13}$ Briefly, $250 \mathrm{mg}$ of bovine thyroglobulin (Sigma) were dissolved in $50 \mathrm{ml}$ of $0.1 \mathrm{M}$ morpholine propane sulphonic acid buffer $(\mathrm{pH} 7 \cdot 0)$, centrifuged $(8000 \mathrm{~g})$ and filtered $(0.2 \mu \mathrm{m})$. The thyroglobulin solution was allowed to react with $10 \mathrm{ml}$ of activated Affi-Gel 15 (BioRad Laboratories) overnight at $4^{\circ} \mathrm{C}$ with shaking. Most $(95 \%)$ of the thyroglobulin was bound to the beads. After blocking the remaining active sites on the gel with $0.1 \mathrm{M}$ ethanolamine for $30 \mathrm{~min}$ at $4^{\circ} \mathrm{C}$, the beads were packed into a column (Pharmacia, Uppsala, Sweden; column c 10/10, $10 \times 100 \mathrm{~mm}$ ) which was then washed at $37^{\circ} \mathrm{C}$ with 20 bed volumes $(120 \mathrm{ml})$ each of pre-warmed basic buffer $(0 \cdot 1 \mathrm{M}$ glycine-sodium hydroxide containing $0.5 \mathrm{M} \mathrm{NaCl}, \mathrm{pH} 10.0)$ and acidic buffer $(0.1 \mathrm{M}$ glycine-hydrochloride containing $0.5 \mathrm{M}$ $\mathrm{NaCl}, \mathrm{pH} 2 \cdot 0$ ), followed by equilibration at $4^{\circ} \mathrm{C}$ with 20 bed volumes of $0.05 \mathrm{M}$ Tris- $\mathrm{HCl}, 0.15 \mathrm{M} \mathrm{NaCl}$, $\mathrm{pH} 7.0$ (TBS). C. difficile culture filtrate $(100 \mathrm{ml})$ was applied to the column at $4^{\circ} \mathrm{C}$. After washing the column with $25 \mathrm{ml}$ of TBS at $4^{\circ} \mathrm{C}$, it was warmed at $37^{\circ} \mathrm{C}$ for $2 \mathrm{~h}$, and thermal elution was performed by washing with $50 \mathrm{ml}$ of pre-warmed TBS at $37^{\circ} \mathrm{C}$. Fractions $(5 \mathrm{ml})$ of the washing at $4^{\circ} \mathrm{C}$ and the eluates obtained at $37^{\circ} \mathrm{C}$ were collected and monitored for absorbance at $280 \mathrm{~nm}\left(\mathrm{~A}_{280}\right)$, cytotoxicity and haemagglutinating activity as described below.

\section{Anion-exchange chromatography}

Two kinds of anion-exchange gel-Q Sepharose FF (Pharmacia) and Mono Q (Pharmacia)-incorporated into a fast protein liquid chromatography (FPLC) apparatus (Pharmacia), ${ }^{16}$ were used to obtain highly purified toxin A as reported previously. ${ }^{14}$ The sample was filtered through a membrane filter $(0.2 \mu \mathrm{m})$ before being applied to the column via a 10-ml Super Loop (Pharmacia). Elution was by a $0-0.1 \mathrm{M} \mathrm{NaCl}$ gradient in $20 \mathrm{mM}$ Tris- $\mathrm{HCl}, \mathrm{pH} 7 \cdot 5$. Each fraction was examined for $A_{280}$, cytotoxicity and haemagglutinating activity. The fractions that were both cytotoxic and haemagglutinating (toxin A) after Q Sepharose FF anion-exchange chromatography were dialysed against $20 \mathrm{~mm}$ Tris- $\mathrm{HCl}, \mathrm{pH} 7 \cdot 5$, overnight at $4^{\circ} \mathrm{C}$ before Mono $\mathrm{Q}$ anion-exchange chromatography.

\section{Cytotoxicity assay}

Cytotoxicity was examined with African green monkey kidney (Vero) cells as described previously. ${ }^{13}$ The cultured cells grown in Eagle's Minimum Essential Medium (MEM) supplemented with calf serum 10\% were used for the assay within 1 day. Two- or 10-fold serial dilutions of samples were prepared in PBS. Each diluted sample $(100 \mu \mathrm{l})$ was added to the cells in a microtitration plate, in the presence of $100 \mu \mathrm{l}$ of maintenance medium (Eagle's MEM containing calf serum $2 \%$ ). The cytotoxic titre (cytotoxic unit; CU/ $100 \mu$ l) was expressed as the highest dilution that induced a $100 \%$ cytopathic effect (CPE) after incubation for $24 \mathrm{~h}$.

\section{Haemagglutination (HA) assay}

This assay ${ }^{10}$ was modified by the use of $1.0 \%$, instead of $2.5 \%$, rabbit red blood cells (RBC). Twofold serial dilutions of samples $(50 \mu \mathrm{l})$ were made in isotonic buffer $(0 \cdot 1 \mathrm{M}$ Tris, $\mathrm{pH} 7 \cdot 2$, containing $50 \mathrm{~mm}$ $\mathrm{NaCl}$ ) in $\mathrm{V}$-bottom microtitration plate wells. An equal volume $(50 \mu \mathrm{l})$ of $1 \%$ rabbit $\mathrm{RBC}$ washed three times with the isotonic buffer was added to each well. After shaking thoroughly, the plate was incubated at $4^{\circ} \mathrm{C}$ for $3 \mathrm{~h}$. The HA titre was assessed macroscopically.

\section{Gel electrophoresis}

Sodium dodecyl sulphate-polyacrylamide gel electrophoresis (SDS-PAGE) was performed by the method of Laemmli ${ }^{17}$ on a $1.5 \mathrm{~mm}$ thick $5 \%$ resolving slab gel. Samples were diluted 1 in 2 in double strength SDS-PAGE sample buffer (pH 6.8 with 125 mM Tris$\mathrm{HCl}-4 \%$ SDS, glycerol $20 \%$, with or without $\beta$ mercaptoethanol $10 \%$ ). After boiling the samples for $3 \mathrm{~min}$, electrophoresis was performed with a constant current of $30 \mathrm{~mA} /$ gel for 2.5-3 h. High mol. wt markers were purchased from BioRad Laboratories (Richmond, CA, USA).

'Native PAGE' was performed with a 4-30\% gradient gel as indicated above for SDS-PAGE, except that SDS and $\beta$-mercaptoethanol were left out of the running buffers, gels and samples. The samples for the native gels were not denatured by heating. After preelectrophoresis at $75 \mathrm{~V}$ for $30 \mathrm{~min}$, samples were loaded and electrophoresis was performed at $125 \mathrm{~V}$ for $18 \mathrm{~h}$. For estimation of $M_{r}$, high $M_{r}$ standards (Pharmacia) were used. Both SDS-PAGE and native PAGE gels were silver stained as instructed by the manufacturers (BioRad Bulletin 1089), or stained with Coomassie Blue R-250.

\section{Protein assay}

Protein concentration was determined by the dyebinding method ${ }^{18}$ with the BioRad protein assay kit. Bovine serum albumin was used as a standard.

\section{Immunoblotting}

After electrophoresis of denatured and reduced toxin, the samples were blotted ${ }^{19,20}$ on to nitrocellulose 
membranes (Schleicher and Schull, Dassel, Germany; BA $83,0.2 \mu \mathrm{m}$ ) with BioRad transblot equipment, operated at $30 \mathrm{~mA}$ for $12 \mathrm{~h}$ and then at $120 \mathrm{~mA}$ for $1 \mathrm{~h}$ in $0.025 \mathrm{M}$ Tris, $0.192 \mathrm{M}$ glycine containing methanol $13 \%$. The nitrocellulose membranes were rinsed with PBS and blocked for $30 \mathrm{~min}$ at room temperature with PBS containing bovine serum albumin $0.18 \%$ and Tween $200 \cdot 1 \%$. The membranes were incubated for $3 \mathrm{~h}$ at room temperature in either mouse A antitoxin or a mouse monoclonal antibody (MAb PCG-4) to toxin A. The former was obtained from a mouse immunised with highly purified and strongly haemagglutinating toxin $\mathrm{A},{ }^{14}$ and the latter was kindly provided by Dr D.M. Lyerly (Virginia Polytechnic Institute and State University). After incubation, the membranes were rinsed three times in PBS and incubated in a 1 in (500-1000) dilution of goat antimouse IgG conjugated with horseradish peroxidase (Sigma) for $2 \mathrm{~h}$ at room temperature. The membranes were rinsed once with PBS and six times with $40 \mathrm{~mm}$ Tris containing $0 \cdot 16 \mathrm{M} \mathrm{NaCl}$, and blotted proteins were detected with 4-chloro-1-napthol (Sigma).

To determine whether native toxin $\mathrm{A}$ and $\mathrm{A}^{\prime}$ were recognised by MAb PCG-4, they were examined by native-PAGE with the BioRad Mini-Protean II Dual Slab Cell. The toxin $\mathbf{A}$ and $\mathbf{A}^{\prime}$ preparations were stacked in an acrylamide $4 \%$ stacking gel and separated in an acrylamide $7 \cdot 5 \%$ resolving gel with a Tris-glycine buffer system ( $25 \mathrm{mM}$ Tris- $\mathrm{HCl}, 192 \mathrm{mM}$ glycine, $\mathrm{pH} 8.3$ ). Approximately $0.6 \mu \mathrm{g}$ of protein was loaded in each lane and electrophoresed at a constant voltage of $200 \mathrm{~V}$ for $1 \mathrm{~h}$. The gel was pre-equilibrated for $30 \mathrm{~min}$ in buffer containing $25 \mathrm{~mm}$ Tris, $192 \mathrm{mM}$ glycine, $\mathrm{pH} 8 \cdot 3$, and the proteins were transferred to nitrocellulose at $100 \mathrm{~V}$ for $1 \mathrm{~h}$ in the same buffer by means of the BioRad Mini Trans-blot Electrophoretic Transfer Cell. After completion of electrophoretic transfer the nitrocellulose membrane was washed (two 5 -min washes) in $20 \mathrm{mM}$ Tris, $500 \mathrm{mM} \mathrm{NaCl}$ buffer, pH 7.5 (TBS). Non-specific binding was blocked by incubation for $1 \mathrm{~h}$ in gelatin $3 \% \mathrm{w} / \mathrm{v}$ in TBS and the membrane was washed (two 5-min washes) in Tween $200.05 \%$ in TBS (TTBS). The membrane was incubated overnight in MAb PCG-4 diluted 1 in 1000 in gelatin $1 \% \mathrm{w} / \mathrm{v}$ in TTBS, and washed (two 5-min washes) in TTBS. This was followed by incubation for $4 \mathrm{~h}$ in rabbit anti-mouse IgG labelled with horseradish peroxidase and diluted 1 in 500 in gelatin $1 \% \mathrm{w} / \mathrm{v}$ in TTBS. The membrane was washed in TTBS (two 5min washes) and in TBS (one 5-min wash) and developed in a substrate solution prepared by adding $30 \mathrm{mg}$ of 4-chloro-1-naphthol in $10 \mathrm{ml}$ of ice cold methanol to $50 \mathrm{ml}$ of TSB containing $\mathrm{H}_{2} \mathrm{O}_{2} 0.015 \%$.

\section{Dialysis of purified toxin A against BHI broth}

In an attempt to show that toxin $\mathrm{A}^{\prime}$ was not simply toxin $A$ to which a soluble receptor from the complex growth medium had attached, purified toxin A in PBS was dialysed against BHI with the same dialysis bag system as that used for the growth of $C$. difficile and toxin production (see above). The HA and cytotoxicity titres of the toxin A preparation were determined just before dialysis and again after dialysis for $48 \mathrm{~h}$ at $37^{\circ} \mathrm{C}$ anaerobically.

\section{Analysis of toxin A produced by C. difficile in a chemically defined medium}

In an additional approach to exclude the possibility that toxin $\mathrm{A}^{\prime}$ was toxin $\mathrm{A}$ combined with a soluble medium component that blocked $H A$ receptors, the BHI medium was replaced by a chemically defined medium $^{21}$ which contained nine amino-acids, five mineral salts, nicotinic acid, riboflavin and the monosaccharide $\mathrm{N}$-acetylglucosamine. $C$. difficile was then cultured by the dialysis bag method and the toxins were purified by Q-Sepharose FF and Mono Q anion-exchange chromatography.

\section{Results}

\section{Mono $Q$ anion-exchange chromatography profile of C. difficile culture filtrate}

To examine the relationship between the cytotoxic and $\mathrm{HA}$ activities of toxin $\mathrm{A}, 0.5 \mathrm{ml}$ of $C$. difficile culture filtrate (protein $1.55 \mathrm{mg} / \mathrm{ml}$, cytotoxicity $6.7 \times$ $10^{7} \mathrm{CU} / 100 \mu \mathrm{l}$, HA titre 64) was fractionated by Mono $\mathrm{Q}$ anion-exchange column chromatography and each fraction $(0.25 \mathrm{ml})$ was examined for cytotoxicity and HA activity (fig. 1). Two peaks of cytotoxicity representing toxins $A$ and $B$ were demonstrated in fractions $35-45$ and $65-75$, which were eluted at $0.27-0.37 \mathrm{M}$ and $0.57-0.67 \mathrm{M} \mathrm{NaCl}$, respectively. The toxin $\mathrm{B}$ fractions showed no $\mathrm{HA}$ activity despite having high titres $\left(10^{7}-10^{8} \mathrm{CU} / 100 \mu \mathrm{l}\right)$ of cytotoxicity, whereas in the toxin A fractions a peak titre (128) of HA activity was detected. Unexpectedly, the peaks of cytotoxicity and $\mathrm{HA}$ activity of toxin $\mathrm{A}$ were not coincident. The highest titre $\left(10^{5}\right)$ of cytotoxicity was detected in fractions 39-40, whereas the HA peak was observed in fraction 41, demonstrating a discordance between peaks of the two activities of toxin A. To highlight this further, a step-wise elution from 0.30 to $0.32 \mathrm{M}$ $\mathrm{NaCl}$ was performed by Mono Q-FPLC after loading the same amounts $(0.5 \mathrm{ml})$ of crude culture filtrate (table I); $0 \cdot 25-\mathrm{ml}$ fractions were collected. In this experiment, the cytotoxicity titre was determined from a two-fold serial dilution to obtain a more exact endpoint. Fraction 2 gave the highest titre $\left(2^{14}\right)$ of cytotoxicity and had an HA titre of 16 . The highest HA titre (32) was detected in fraction 3, which had a cytotoxicity titre of $2^{13}$. More significantly, fraction 1 , which also had a cytotoxicity titre of $2^{13}$, had no HA activity. As fractions $1-3$ eluted at the same concentration of $\mathrm{NaCl}(0.30 \mathrm{M})$ the discordance between the peaks of the two biological activities was not due to 


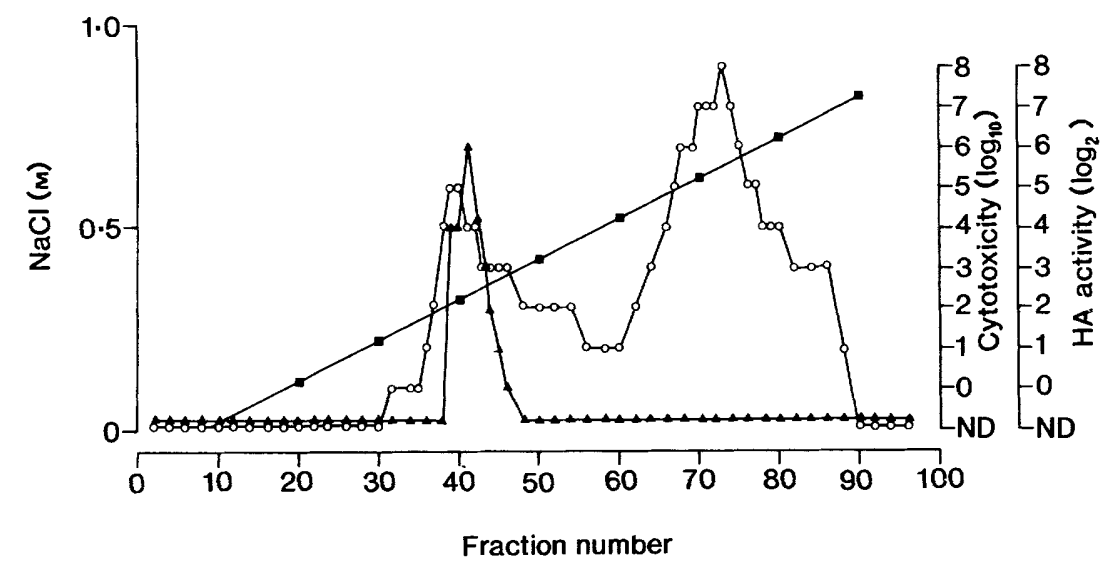

Fig. 1. Mono Q-FPLC profile of $C$. difficile culture filtrate $(0.5 \mathrm{ml})$ after elution with $0-1 \cdot 0 \mathrm{M} \mathrm{NaCl} ; 0 \cdot 25-\mathrm{ml}$ fractions were collected and examined for cytotoxicity $(\mathrm{O})$ and $\mathrm{HA}$ activity $(\boldsymbol{\Delta})$. ( $(\boldsymbol{\square}) \mathrm{NaCl}$ concentration $(\mathrm{M})$.

Table I. Relationship between cytotoxicity and HA activity of $C$. difficile toxin A fractions separated by FPLC with a Mono Q anion-exchange column

\begin{tabular}{rc|cc}
\hline $\begin{array}{c}\text { Fraction } \\
\text { no. }\end{array}$ & $\begin{array}{c}\mathrm{NaCl} \\
(\mathrm{M})\end{array}$ & $\begin{array}{c}\text { Cytotoxicity } \\
(\mathrm{CU} / 100 \mu \mathrm{l})\end{array}$ & $\begin{array}{c}\text { HA activity } \\
\text { (titre) }\end{array}$ \\
\hline 1 & $0 \cdot 30$ & $2^{13}$ & $<1$ \\
2 & $0 \cdot 30$ & $2^{14}$ & 16 \\
3 & $0 \cdot 30$ & $2^{13}$ & 32 \\
4 & $0 \cdot 30$ & $2^{10}$ & 16 \\
5 & $0 \cdot 31$ & $2^{9}$ & 4 \\
6 & $0 \cdot 31$ & $2^{9}$ & 2 \\
7 & $0 \cdot 31$ & $2^{9}$ & 1 \\
8 & $0 \cdot 31$ & $2^{8}$ & 1 \\
9 & $0 \cdot 32$ & $2^{7}$ & $<1$ \\
10 & $0 \cdot 32$ & $2^{6}$ & $<1$ \\
11 & $0 \cdot 32$ & $2^{5}$ & $<1$ \\
12 & $0 \cdot 32$ & $2^{5}$ & \\
\hline
\end{tabular}

slight differences in $\mathrm{NaCl}$ concentration in the two assays.

\section{Analysis of purified toxin $A$}

A similar experiment was next made with pure toxin A, instead of with crude culture filtrate. The purification procedure consisted of three sequential chromatographic steps - thyroglobulin affinity (TG) chromatography, Q-Sepharose FF anion-exchange chromatography, and Mono $\mathrm{Q}$ anion-exchange chromatography. When loaded on to a Q-Sepharose FF column, the thermally eluted TG toxin A specimen (TG fractions $26-29,20 \mathrm{ml}$ ) eluted maximally at 0.44 $0.46 \mathrm{M} \mathrm{NaCl}$ (fraction 24) with a cytotoxic titre of $2^{12}$ and an HA titre of 64. Fractions corresponding to toxin A (fractions $23-25,6 \mathrm{ml}$ ) were loaded on to a Mono $Q$ column and subjected to $0-1.0 \mathrm{M} \mathrm{NaCl}$ elution. Small fractions $(0.25 \mathrm{ml})$ were collected and examined for cytotoxicity and HA activity (table II). Discordance was noted between the peaks of the two activities, though it was much less striking than with the culture filtrate. This was to be expected (see below) because non-haemagglutinating toxin $\mathrm{A}$ would have been lost as a result of the thyroglobulin affinity purification step.

\section{Analysis of TG chromatography unbound material for non-or weakly haemagglutinating toxin $A$}

The twin peaks of biological activity described above suggested the existence of a variant of toxin $A$ with little or no HA activity. Such a variant would be expected to pass more readily through a TG column,

Table II. Cytotoxicity and HA activity of the fractions separated by FPLC with a Mono Q anionexchange column from highly purified toxin A or thyroglobulin (TG)-unbound toxin A preparation

\begin{tabular}{|c|c|c|c|c|c|}
\hline \multirow{2}{*}{$\begin{array}{c}\text { Fraction } \\
\text { no. }\end{array}$} & \multirow{2}{*}{$\begin{array}{c}\mathrm{NaCl} \\
(\mathrm{M})\end{array}$} & \multicolumn{2}{|c|}{ Highly purified toxin A } & \multicolumn{2}{|c|}{ TG-unbound toxin A } \\
\hline & & $\begin{array}{l}\text { Cytotoxicity } \\
(\mathrm{CU} / 100 \mu \mathrm{l})\end{array}$ & $\begin{array}{c}\text { HA activity } \\
\text { (titre) }\end{array}$ & $\begin{array}{l}\text { Cytotoxicity } \\
(\mathrm{CU} / 100 \mu \mathrm{l})\end{array}$ & $\begin{array}{c}\text { HA activity } \\
\text { (titre) }\end{array}$ \\
\hline 36 & $0 \cdot 28$ & $<2^{3}$ & $<2$ & $<2^{3}$ & $<2$ \\
\hline 37 & 0.29 & $<2^{3}$ & $<2$ & $2^{6}$ & $<2$ \\
\hline 38 & 0.30 & $2^{11}$ & 4 & $2^{13}$ & $<2$ \\
\hline 39 & $0 \cdot 31$ & $2^{13}$ & 32 & $2^{14}$ & $<2$ \\
\hline 40 & 0.32 & $2^{12}$ & 64 & $2^{13}$ & 2 \\
\hline 41 & 0.33 & $2^{10}$ & 16 & $2^{13}$ & 2 \\
\hline 42 & $0 \cdot 34$ & $2^{8}$ & 4 & $2^{11}$ & $<2$ \\
\hline 43 & 0.35 & $2^{6}$ & $<2$ & $2^{10}$ & $<2$ \\
\hline
\end{tabular}


as the receptors responsible for $\mathrm{HA}$ and interaction with bovine thyroglobulin are thought to be the same. ${ }^{12}$ Therefore, thyroglobulin unbound fractions (TG fractions 10-13, $20 \mathrm{ml}$ ), which contained toxin B and unknown proteins, were also analysed by $\mathrm{Q}$ Sepharose FF anion-exchange column chromatography. A fraction (fraction 24) eluting at 0.44-0.46 M $\mathrm{NaCl}$, the point at which toxin A eluted, had a cytotoxic titre of $2^{13}$ but an HA titre of only 2 . This confirmed that the HA activity did not always correspond to the degree of cytotoxicity of toxin $A$.

This variant $\left(A^{\prime}\right)$ of toxin $A$ was further purified by subjecting Q-Sepharose FF fractions $23-25(6 \mathrm{ml})$ to Mono $Q$ anion-exchange column chromatography. Each $0 \cdot 25-\mathrm{ml}$ fraction was collected and examined for cytotoxicity and HA activity (table II). The highest titre of cytotoxicity $\left(2^{14}\right)$ was detected in fraction 39 , eluting at $0.31 \mathrm{M} \mathrm{NaCl}$. Interestingly, this fraction had no detectable HA titre. In fractions $40-41$, an HA titre of only 2 was detected. These results give further confirmation of the existence of a variant of toxin $\mathbf{A}$.

\section{Effect of growth in a chemically defined medium and of dialysis of toxin A against BHI broth on concentration of toxin $A^{\prime}$}

The dialysis of a purified toxin A preparation against BHI had no effect on the cytotoxicity or HA titres, which remained at $2^{13}$ and 64 respectively. Toxin $\mathbf{A} / \mathbf{A}^{\prime}$, produced by growth in a chemically defined medium and purified by Q-Sepharose FF and Mono $Q$ anion-exchange chromatography, yielded seven 1-ml fractions which eluted where toxin $\mathbf{A} / \mathbf{A}^{\prime}$ would be expected. The cytotoxic titre of these fractions ranged from $2^{8}$ to $2^{14}$, but none had an HA titre.

\section{Polyacrylamide gel electrophoresis (PAGE)}

Equal volumes ( $40 \mu \mathrm{l})$ of highly purified toxin A and

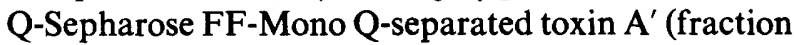
39) were compared by native and SDS-PAGE (figs. 24). After native gel electrophoresis, only one band $(540 \mathrm{Kda})$ of toxin A was detected by silver stain. In contrast, TG-unbound Q Sepharose FF-Mono Qseparated toxin $\mathrm{A}^{\prime}$ exhibited an additional six faint bands $(490,430,230,130,105$ and $40 \mathrm{Kda})$.

The SDS-PAGE profiles of toxins $A$ and $A^{\prime}$ (fraction 39 ), both with and without reduction with $\beta$-mercaptoethanol, are shown in figs. 3 and 4 . In non-reducing conditions, one major band (a doublet) of $240 \mathrm{Kda}$, nine minor bands and many faint bands were detected from highly purified toxin A (fig. 3). Although the same profile was obtained from toxin $A^{\prime}$ an additional five bands smaller than $45 \mathrm{Kda}$ were also detected (fig. 3).

Analysis of these toxin A and $A^{\prime}$ fractions by SDSPAGE in reducing conditions (fig. 4) showed that, in addition to the major band of $240 \mathrm{Kda}$, there were numerous bands common to both preparations, and several bands $(<45 \mathrm{Kda})$ apparently unique to the toxin $\mathbf{A}^{\prime}$ preparation.

\section{Immunoblotting of toxins $A$ and $A^{\prime}$}

As toxins $\mathrm{A}$ and $\mathrm{A}^{\prime}$ have similar physico-chemical properties (mol. wt; breakdown profile after denaturation with or without reduction; and charge based on point of elution after anion-exchange chromatography) it was decided to investigate their antigenic similarities. Immunoblotting with mouse mono-specific $A$ antitoxin showed some differences between toxins $A$ and $A^{\prime}$ (fig. 5A), but the major $240-K d a$ peptide was strongly developed in both toxin preparations. In non-reducing conditions (lanes 1 and 2), five minor bands of $>240 \mathrm{Kda}$ were developed more strongly in toxin $\mathbf{A}$ than in $\mathbf{A}^{\prime}$. Similarly, five faint bands $(96,86,70,60$ and $38 \mathrm{Kda})$ were apparent in toxin $\mathbf{A}$ but not in $\mathbf{A}^{\prime}$ (not seen on photographic reproduction). In reducing conditions (lanes 3 and 4),

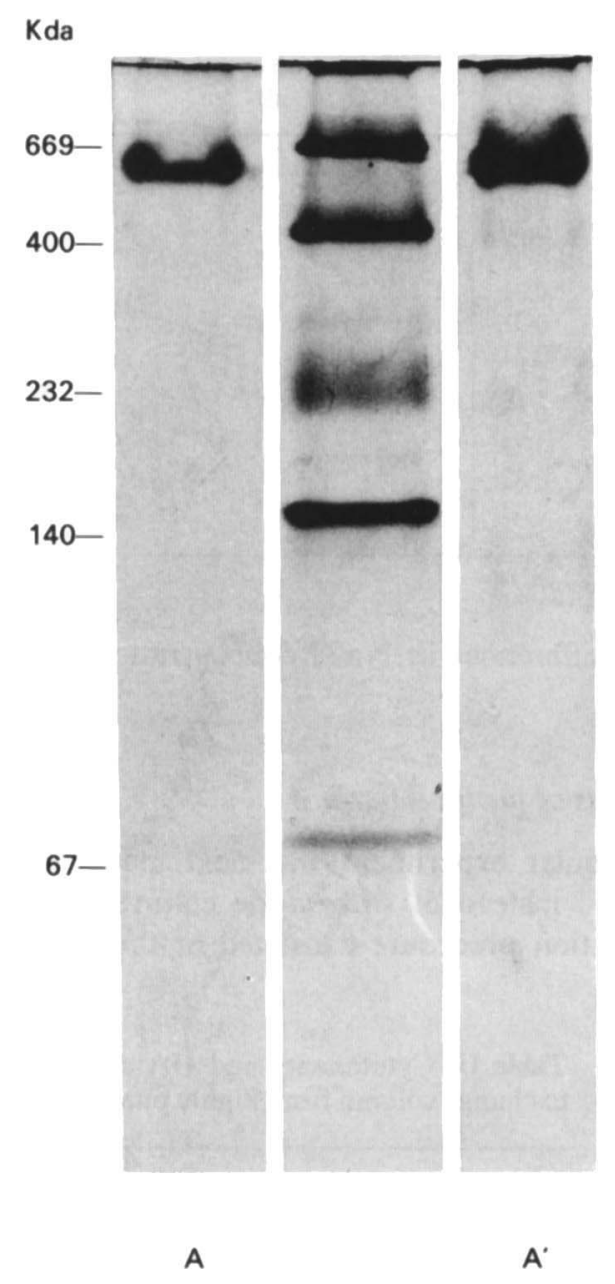

Fig. 2. Native PAGE of Mono Q-FPLC-separated toxin $A$ and toxin $A^{\prime}$ fractions. Thyroglobulin affinity-QSepharose FF-separated toxin $A(20 \mathrm{ml})$ or thyroglobulin affinity unbound Q-Sepharose FFseparated toxin $A^{\prime}(20 \mathrm{ml})$ was further purified by Mono Q-FPLC; $0 \cdot 25-\mathrm{ml}$ fractions were collected after $0-1.0 \mathrm{M} \mathrm{NaCl}$ elution. Peak fraction $39(40 \mu \mathrm{l})$ of either toxin $A$ or $A^{\prime}$ was loaded on to a 4-30\% gradient gel without SDS. After electrophoresis $(125 \mathrm{~V}, 18 \mathrm{~h})$, the gel was developed with silver. Centre lane: mol. wt standardsthyroglobulin $(669 \mathrm{Kda})$, ferritin $(440 \mathrm{Kda})$, catalase $(232 \mathrm{Kda})$, lactate dehydrogenase $(140 \mathrm{Kda})$, bovine serum albumin $(67 \mathrm{Kda})$ (Pharmacia). 


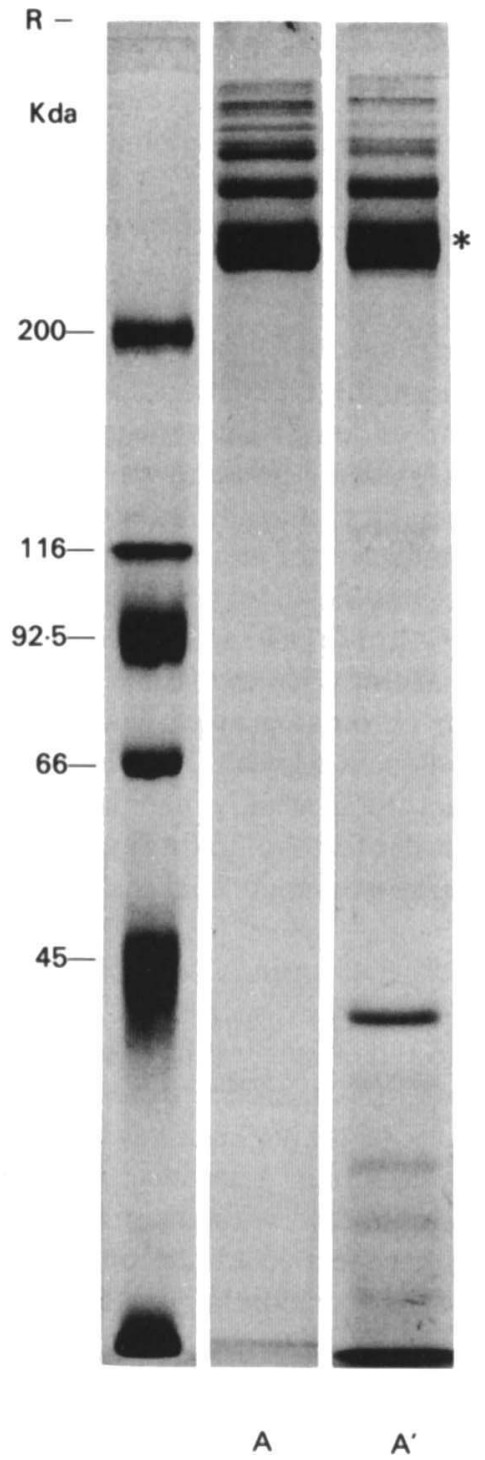

Fig. 3. SDS-PAGE in non-reducing conditions of Mono Q-FPLCseparated toxin $A$ and toxin $A^{\prime}$ fractions. From each peak fraction eluted from the Mono $Q$ column (fraction 39 for both toxin preparations), $40 \mu \mathrm{l}$ were mixed with an equal volume of sample buffer without $\beta$-mercaptoethanol, and boiled for $3 \mathrm{~min}$. After electrophoresis $(30 \mathrm{~mA}, 2 \cdot 5-3 \mathrm{~h})$, the gel was developed by silver. First lane: mol. wt standards-myosin $(200 \mathrm{Kda}), \beta$-galactosidase $(116 \mathrm{Kda})$, phosphorylase $\mathrm{B}(92.5 \mathrm{Kda})$, bovine serum albumin (66 Kda; BioRad), ovalbumin (45 Kda). *Doublet at $240 \mathrm{Kda}$.

three further bands $(175,160$ and $155 \mathrm{Kda})$ were more intensely developed in toxin $\mathrm{A}$ than in $\mathrm{A}^{\prime}$, and the faint bands at 96 (not seen on photographic reproduction), 86, 70, 60 and $38 \mathrm{Kda}$ were more apparent (lane 3).

In contrast, immunoblotting with MAb PCG-4 gave patterns (figs. 5B and 6) different from those produced by mono-specific $A$ antitoxin. In nonreducing conditions, five bands larger than the 240$\mathrm{Kda}$ doublet developed to a similar extent in both toxins $\mathrm{A}$ and $\mathrm{A}^{\prime}$ (fig. 5B; lanes 1 and 2). In reducing conditions, many bands developed, in addition to the major 240-Kda band in toxin $\mathrm{A}^{\prime}$ (fig. 5B; lane 4). In contrast, toxin A exhibited three clear bands: the major one of $240 \mathrm{Kda}$, and two bands of 160 and $155 \mathrm{Kda}$ (fig. 5B; lane 3). The 160-Kda band was more strongly developed in toxin $\mathrm{A}$ than in $\mathrm{A}^{\prime}$, the opposite being true for the $155 \mathrm{Kda}$ band. In both reducing and non-reducing conditions, four bands $(195,180,175$ and $125 \mathrm{Kda}$ ) were detected only in toxin $\mathrm{A}^{\prime}$ (fig. $5 \mathrm{~B}$; lanes 2 and 4). Both native toxin $A$ and toxin $A^{\prime}$ were recognised by MAb PCG-4 in immunoblots after transfer of the toxins from a native gel (fig. 6). An additional minor band was recognised in toxin $\mathrm{A}^{\prime}$.

\section{Discussion}

At least two toxins, toxin A (enterotoxin) and toxin B (cytotoxin) are produced by $C$. difficile. Some investigators have reported an additional enterotoxin which is unstable and induces fluid accumulation without haemorrhage in rabbit ligated ileal loops, ${ }^{5,22}$ but these findings need to be confirmed. Among these

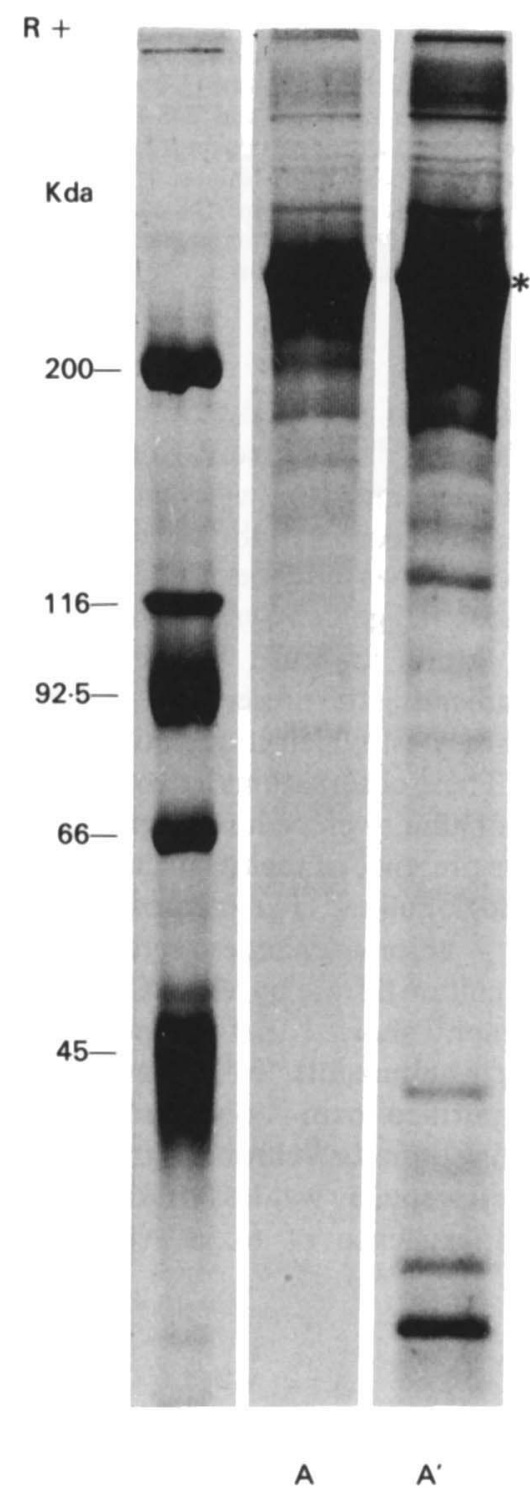

Fig. 4. SDS-PAGE in reducing conditions of Mono Q-separated toxin $A$ and $A^{\prime}$ fractions. For each toxin preparation, $40 \mu \mathrm{l}$ of peak fraction 39 eluted from the Mono $Q$ column were mixed with an equal volume of sample buffer with $\beta$-mercaptoethanol $5 \%$. First lane, mol. wt markers (see fig. 3). *Major $240 \mathrm{Kda}$ component. 
A

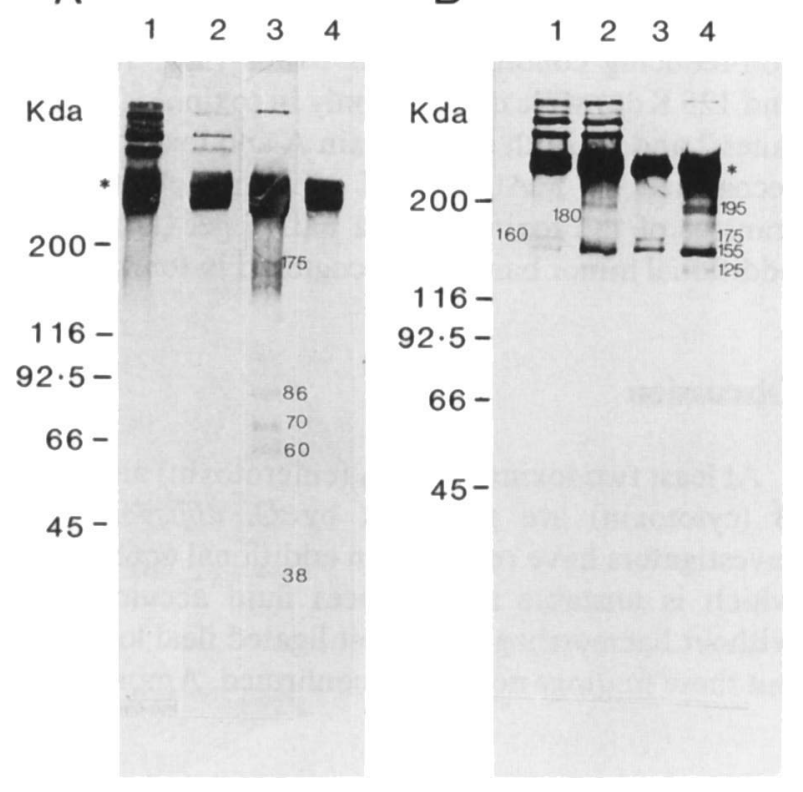

Fig. 5. Immunoblot analysis of toxins $A$ and $A^{\prime}$. Highly purified toxin A (7 $\mu \mathrm{g}$ ) (lanes 1 and 3) and Mono Q separated toxin $\mathrm{A}^{\prime}(7 \mu \mathrm{g})$ ( 2 and 4 ) were loaded on to a $5 \%$ gel and SDS-PAGE was performed in non-reducing (lanes 1 and 2 ) or reducing ( 3 and 4 ) conditions. (A) Mouse monospecific anti-toxin A (diluted 1 in 500) was used for reaction with the transferred proteins. (B) Mouse MAb to toxin A (PCG-4; diluted 1 in 500) was used for reaction with the transferred proteins. *Major $240 \mathrm{Kda}$ component.

toxins, A has been regarded as the most important virulence factor, ${ }^{23,24}$ because it-but not toxin Binduces fluid accumulation with haemorrhage in the ligated intestinal loops of rabbits. ${ }^{5,25}$ The enterotoxicity of toxin $A$ has also been shown in infant or suckling mice ${ }^{6}$ and golden Syrian hamsters. ${ }^{26}$

Toxin A binds to brush border membranes of hamsters, indicating the presence of a receptor, and to rabbit erythrocytes, which it agglutinates at $4^{\circ} \mathrm{C}$ but not $37^{\circ} \mathrm{C} .{ }^{10}$ These observations led to the development of an efficient affinity procedure for purifying toxin $\mathrm{A}$, based on the presence of the trisaccharide receptor on bovine thyroglobulin. ${ }^{12}$ The method is improved by subsequent anion-exchange chromatography. ${ }^{13}$ Analysis of culture filtrate by Mono $Q$ anion-exchange chromatography showed that the peaks of $\mathrm{HA}$ and cytotoxicity in culture filtrate did not coincide; neither did they in purified toxin A obtained by the modified thyroglobulin affinity chromatography method ${ }^{13}$ though the discrepancy was less striking. These results suggest the existence of toxin A molecules with

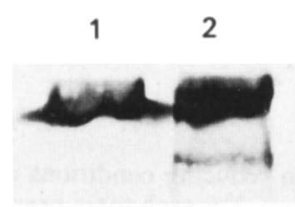

Fig. 6. Immunoblot analysis of toxins $A$ and $A^{\prime}$ with MAb PCG-4 after transfer from a polyacrylamide $7.5 \%$ native gel. Lane $1:$ highly purified toxin $\mathrm{A}(0 \cdot 6 \mu \mathrm{g})$ and lane 2 : toxin $\mathrm{A}^{\prime}(0 \cdot 6 \mu \mathrm{g})$. differing HA properties, which may explain a reported micro-heterogeneity of toxin A. ${ }^{27}$ Poor or nonhaemagglutinating forms, if present, would more readily pass through the thyroglobulin affinity column at $4{ }^{\circ} \mathrm{C}$. Analysis of thyroglobulin unbound material, which contained toxin B and many other proteins, demonstrated toxin $\mathbf{A}$ with full cytotoxicity but negligible HA properties. This preparation, toxin $\mathrm{A}^{\prime}$, could be partly purified by $\mathrm{Q}$ Sepharose FF anionexchange chromatography and further purified by Mono $Q$ anion-exchange chromatography.

The final toxin $A^{\prime}$ preparation contained a few minor contaminant proteins in addition to a major $540-\mathrm{Kda}$ protein, but the relatively pure material from Mono Q fractions 38-40 (eluted at $0 \cdot 30-0 \cdot 32 \mathrm{M} \mathrm{NaCl}$ ) had a low HA titre ( 2 or less) but was highly cytotoxic $\left(2^{13}-2^{14}\right)$. That this was not toxin A denatured during thyroglobulin chromatography, leaving the binding components associated with the column, was evident from the fact that weakly haemagglutinating but potently cytotoxic forms of toxin A were detected even on direct anion-exchange analysis of crude culture filtrate.

It is unlikely that toxin $A^{\prime}$ was simply the result of interaction of toxin A with BHI components that blocked the Gal $\alpha 1-3 \mathrm{Gal} \beta 1-4 \mathrm{GlcN} A \mathrm{c}$ receptors on the toxin molecule and thereby prevented HA. Firstly, dialysis of purified toxin A against BHI broth did not result in any loss of HA activity; had soluble BHI components interacted with toxin A, some such loss would have been expected. Secondly, growth in a chemically defined medium yielded predominantly toxin $\mathrm{A}^{\prime}$; it also leads to a diminished production of proteases, ${ }^{28}$ which may play a part in the conversion of toxin $\mathrm{A}^{\prime}$ to toxin $\mathrm{A}$.

Denaturation of toxin A by SDS, with or without $\beta$ mercaptoethanol, was shown previously to cause dissociation into a major $240-\mathrm{Kda}$ protein (appearing as a doublet) and 10 minor and 27 faint bands (nonreduced), and a major $240-\mathrm{Kda}$ protein and four minor and 31 faint bands (reduced). ${ }^{14} \mathrm{~A}$ similar dissociation has been shown by others. ${ }^{27,29}$ Highly purified toxin A and Q Sepharose-FF-Mono Q-separated toxin $\mathrm{A}^{\prime}$ were similar but not identical. It proved impossible to elute cytotoxicity and HA activity from the SDSPAGE gels in order to examine the bands associated specifically with either activity.

Even though toxin $\mathbf{A}^{\prime}$ exhibited no HA activity, it was recognised by MAb PCG-4 in immunoblots of its denatured non-reduced and denatured reduced forms in a pattern similar to that of toxin A.

This observation indicated that toxin $\mathrm{A}^{\prime}$ differed from toxin A configurationally, the HA components being masked in the native molecule. However, both toxins $\mathbf{A}$ and $\mathbf{A}^{\prime}$ were readily recognised in an enzyme immunoassay (unpublished data) and in an immunoblot of native toxin. This may indicate that MAb PCG-4 recognises an epitope different from that responsible for binding and prevents $\mathrm{HA}$ as a result of steric hindrance, or that the relevant epitope in toxin 
$\mathrm{A}^{\prime}$ may be accessible to MAb PCG-4 but not to the receptor on rabbit erythrocytes.

Because toxin $\mathrm{A}^{\prime}$ possessed cytotoxic but not HA activity, the receptors associated with these two functions (and, by analogy, binding to brush-border membranes and enterotoxicity) would appear to be different. This accords with the observation that PCG4 neutralises the enterotoxic but not cytotoxic activity of toxin $A .{ }^{24,29}$ On the other hand, mouse embryonal carcinoma cells that produce high amounts of the trisaccharide Gal $\alpha 1-3 \mathrm{Gal} \beta 1-4 \mathrm{GlcN}$ Ac are much more sensitive to the cytotoxic activity of toxin $A$ than are

\section{References}

1. Bartlett JG, Chang TW, Gurwith M, Gorbach SL, Onderdonk AB. Antibiotic-associated pseudomembranous colitis due to toxin-producing clostridia. N Engl J Med 1978; 298: 531 534.

2. Borriello SP, Larson HE. Antibiotic and pseudomembranous colitis. J Antimicrob Chemother 1981; 7 Suppl A : 53-62.

3. George WL, Sutter VL, Goldstein EJC, Ludwig SL, Finegold SM. Aetiology of antimicrobial-agent-associated colitis. Lancet 1978 ; 1 : 802-803.

4. Larson HE, Price AB, Honour P, Borriello SP. Clostridium difficile and the ætiology of pseudomembranous colitis. Lancet 1978; 1: 1063-1066.

5. Banno $Y$, Kobayashi $T$, Kono $H$, Watanabe $K$, Ueno $K$, Nozawa $Y$. Biochemical characterization and biologic actions of two toxins (D-1 and D-2) from Clostridium difficile. Rev Infect Dis 1984; 6 Suppl 1: S11-S20.

6. Lyerly DM, Lockwood DE, Richardson SH, Wilkins TD. Biological activities of toxins $A$ and $B$ of Clostridium difficile. Infect Immun 1982; 35: 1147-1150.

7. Mitchell TJ, Ketley JM, Haslam SC et al. Effect of toxin A and $\mathrm{B}$ of Clostridium difficile on rabbit ileum and colon. Gut 1986; $27: 78-85$.

8. Borriello SP, Barclay FE, Welch AR et al. Host and microbial determinants of the spectrum of Clostridium difficile mediated gastrointestinal disorders. In : Erlandsen SL, Jordan MC, Wells CL, Rusch V (eds) Microecology and therapy, vol 15. Herborn-Dill, FRG, Institut für Mikroökologie. 1985: 231 .

9. Lyerly DM, Saum KE, MacDonald DK, Wilkins TD. Effects of Clostridium difficile toxins given intragastrically to animals. Infect Immun 1985; 47: 349-352.

10. Kriven HC, Clarke GF, Smith DF, Wilkins TD. Cell surface binding site for Clostridium difficile enterotoxin: evidence for a glycoconjugate containing the sequence Gal $\alpha 1-3 \mathrm{Gal} \beta 1$ 4GlcNAc. Infect Immun 1986; 53: 573-581.

11. Tucker KD, Wilkins TD. Toxin A of Clostridium difficile binds to the human carbohydrate antigens $\mathrm{I}, \mathrm{X}$ and $\mathrm{Y}$. Infect Immun 1991 ; 59 : 73-78.

12. Krivan HC, Wilkins TD. Purification of Clostridium difficile toxin A by affinity chromatography on immobilized thyroglobulin. Infect Immun 1987; 55: 1873-1877.

13. Kamiya S, Reed PJ, Borriello SP. Analysis of purity of Clostridium difficile toxin A derived by affinity chromatography on immobilized bovine thyroglobulin. FEMS Microbiol Lett 1988; 56: 331-336.

14. Kamiya S, Reed PJ, Borriello SP. Purification and characterisation of Clostridium difficile toxin A by bovine thyroglobulin affinity chromatography and dissociation in denaturing conditions with or without reduction. J Med Microbiol 1989; 30: $69-77$. those that do not. ${ }^{30}$ It seems possible that toxin $\mathrm{A}$ uses a variety of different cell receptors for the initial binding step to cells in tissue culture, and that the Gal $\alpha 1-3 \mathrm{Gal} \beta 1-4 \mathrm{GlcN} A \mathrm{c}$ trisaccharide is simply one of the preferred ones.

The evidence presented strongly indicates that there is a form of toxin A (probably a pro-toxin) that has a weak ability to haemagglutinate rabbit erythrocytes but is potently cytotoxic.

S.K. was the recipient of a Wellcome Research Fellowship. We thank M. Krishna, R. Davies and S. Hyde for their help.

15. Thelestam M, Florin I. Cytopathogenic action of Clostridium difficile toxins. J Toxicol-Toxin Rev 1984; 3: 139-180.

16. Borriello SP, Barclay FE, Reed PJ, Welch AR, Brown JD, Burdon DW. Analysis of latex agglutination test for Clostridium difficile toxin A (D-1) and differentiation between $C$. difficile toxins $\mathrm{A}$ and $\mathrm{B}$ and latex reactive protein. J Clin Pathol 1987; 40: 573-580.

17. Laemmli UK. Cleavage of structural proteins during the assembly of the head of bacteriophage T4. Nature 1970; 227: 680-685.

18. Bradford MM. A rapid and sensitive method for the quantitation of microgram quantities of protein utilizing the principle of protein-dye binding. Anal Biochem 1976; 72 : 248-254.

19. Burnette WN. "Western blotting". Electrophoretic transfer of proteins from sodium dodecyl sulphate-polyacrylamide gels to unmodified nitrocellulose and radiographic detection with antibody and radioiodinated protein A. Anal Biochem 1981; 112: 195-203.

20. Towbin H, Staehelin T, Gordon J. Electrophoretic transfer of proteins from polyacrylamide gels to nitrocellulose sheets: procedure and some applications. Proc Natl Acad Sci USA $1979 ; 76: 4350-4354$

21. Seddon SV, Borriello SP. A chemically defined and minimal medium for Clostridium difficile. Lett Appl Microbiol 1989; 9: 237-239.

22. Giuliano M, Piemonte F, Gianfrilli PM. Production of an enterotoxin different from toxin $\mathrm{A}$ by Clostridium difficile. FEMS Microbiol Lett 1988; 50: 191-194.

23. Borriello SP, Davies HA, Kamiya S, Reed PJ, Seddon S. Virulence factors of Clostridium difficile. Rev Infect Dis 1990; 12 Suppl 2: S185-S191.

24. Lyerly DM, Krivan HC, Wilkins TD. Clostridium difficile: its disease and toxins. Clin Microbiol Rev 1988; 1 : 1-18.

25. Taylor NS, Thorne GM, Bartlett JG. Comparison of two toxins produced by Clostridium difficile. Infect Immun 1981; 34: 1036-1043.

26. Libby JM, Jortner BS, Wilkins TD. Effects of the two toxins of Clostridium difficile in antibiotic-associated cecitis in hamsters. Infect Immun 1982; 36: 822-829.

27. Rautenberg P, Stender F. Characterization of immunogenic p230 as the toxin A of Clostridium difficile. FEMS Microbiol Lett 1986; 37 : 1-7.

28. Seddon SV, Davies HA, Borriello SP. The effect of nutrition on the expression of known and putative virulence factors of Clostridium difficile. Microb Ecol Hlth Dis 1990; 4: 303309.

29. Lyerly DM, Phelps CJ, Toth J, Wilkins TD. Characterization of toxins A and B of Clostridium difficile with monoclonal antibodies. Infect Immun 1986; 54: 70-76.

30. Tucker KD, Carrig PE, Wilkins TD. Toxin A of Clostridium difficile is a potent cytotoxin. J Clin Microbiol 1990; 28: 869871. 